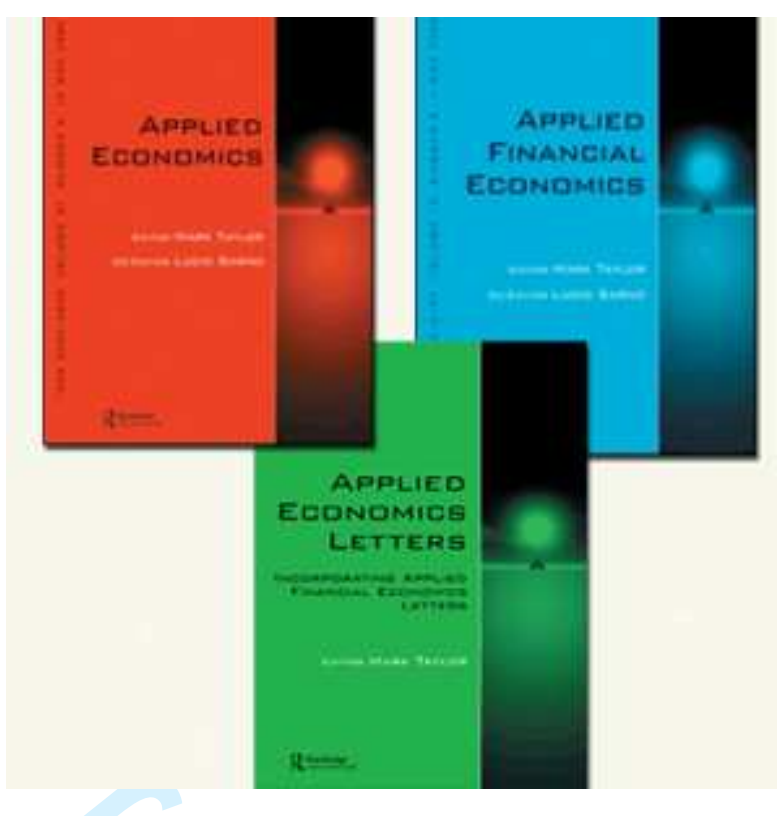

\title{
The determinants of internal migration in a developing country: quantitative evidence for Indonesia, 1930-2000
}

\begin{tabular}{|c|c|}
\hline Journal: & Applied Economics \\
\hline Manuscript ID: & APE-2010-0371.R1 \\
\hline Journal Selection: & Applied Economics \\
\hline $\begin{array}{r}\text { Date Submitted by the } \\
\text { Author: }\end{array}$ & 29-Jan-2011 \\
\hline Complete List of Authors: & $\begin{array}{l}\text { van Lottum, Jelle; University of Cambridge, Geography Department } \\
\text { Marks, Daan; International Institute of Social History }\end{array}$ \\
\hline JEL Code: & $\begin{array}{l}\text { J61 - Geographic Labor Mobility } \mid \text { Immigrant Workers }<J 6 \text { - Mobility, } \\
\text { Unemployment, and Vacancies < J - Labor and Demographic } \\
\text { Economics, C50 - General < C5 - Econometric Modeling < C - } \\
\text { Mathematical and Quantitative Methods }\end{array}$ \\
\hline Keywords: & $\begin{array}{l}\text { Indonesia, Gravity model of migration, Economic development, } \\
\text { Migration }\end{array}$ \\
\hline
\end{tabular}

\section{SCHOLARONE \\ Manuscripts}


The determinants of internal migration in a developing country: quantitative evidence for Indonesia, 1930-2000

J. van Lottum $^{\mathrm{a} *}$ and D. Marks ${ }^{\mathrm{b}}$

a Cambridge Group for the History of Population and Social Structure, Geography Department, University of Cambridge, Cambridge, UK

b International Institute for Social History Amsterdam / Faculty of Economics, Utrecht University, Utrecht, the Netherlands

* Corresponding author. E-mail: jv266@ cam.ac.uk; Tel: +44(0)1223 333194

Keywords: Internal Migration; Indonesia; Gravity Model; Policy; Development JEL codes: J61; J68; N15; O15

\begin{abstract}
This study specifies and estimates a gravity model for interprovincial migration in Indonesia. Analyzing five cross-sections for Indonesia's 26 provinces for 5 survey years between 1930 and 2000 we show that throughout the twentieth century economic factors were more important in the explanation of interprovincial migration patterns in Indonesia than planned migration policy aimed at the redistribution of the population. In addition, our regression analysis demonstrates that the urban primacy of Jakarta, Indonesia's capital, had a strong effect on the direction and size of migration flows. Our findings thus suggest that the costly government-supported migration is not very successful and that a strongly centralized government induces migration flows to the capital. These findings have policy implications for other developing countries.
\end{abstract}




\section{Introduction}

Immigration is a controversial issue in developed and developing countries alike, and increasingly economists have dealt with explaining its causes and effects (Lewer and Van den Berg, 2008). The economic approach to immigration has, however, been mainly applied to international migration, and mostly on migration flows between developed countries. The number of empirical studies that attempt to model internal migration in developing countries is still relatively limited, and the lion's share of such studies has relied on the work of Harris and Todaro (1970) which focuses on rural-urban migration (a two sector model). The present article has a different aim and methodology in that it studies developments in Indonesia's interprovincial migration flows between 1930 and 2000 by applying a modified gravity model. Using Borjas' (1989) concept of immigrant markets and their gravitational behaviour we aim to study the main determinants of migration flows in Indonesia during a period where it changed from being part of the Dutch colonial empire to one of the largest economies in (Southeast) Asia. Our key aim is to determine which factors have driven internal population movements in Indonesia between 1930 and 2000. We are particularly interested in the effect of deliberate government programs to promote migration from specific provinces, and how the (changing) economic and social conditions in the sending and receiving provinces influenced the inclination to migrate.

We have specifies and estimated a modified gravity model of migration using migration flows for five survey years covering seven decades: 1930, 1971, 1980, 1990 and 2000. The approach in estimating the model for migration is similar to that of Lewer and Van den Berg (2007) and Karemera et al. (2000) the only difference 
being that they applied a gravity model on international migration while our model aims the estimate a model of internal population movements. In addition, following in particular Karemera et al.'s (2000) successful methodology of ranking the migration elasticities (or the beta-coefficients) for the five survey years, we aim to compare the importance of the determinants of internal migration in Indonesia through time.

This article is in five parts. Section II presents an outline of internal migration in Indonesia between 1930 and 2000. Section III lays out the theoretical assumptions of our model, and discusses the data and the econometric procedures we applied in this study. Section IV discusses the results. Finally, in section V we will present our conclusions.

\section{Internal migration in Indonesia, 1930-2000}

Indonesia is an important case study. It is the fourth most populous country in the world with more than 200 million inhabitants in 2000 . Furthermore, it is the world's largest archipelago, consisting of $c a 17,000$ islands which span more than 5,000 km eastward from Sabang in northern Sumatra to Merauke in Irian Jaya (see Map 1). If one would superimpose a map of Indonesia over one of Europe, one will find that it stretches from Ireland to Iran; compared to the United States, it covers the area from California to Bermuda.

The available sources for the twentieth century show that internal migration in Indonesia is far from a recent phenomenon. Already under Dutch rule - Indonesia declared independence in 1945, which was only acknowledged by the Dutch in 1949 - it already had a highly geographically mobile population. According to the 1930 
population census no less than $11.5 \%$ of the total indigenous population of Indonesia lived outside their district of birth (Volkstelling, 1930) although only half of this (5.6\%) moved beyond the provincial borders. Still, in absolute figures this boils down to a number of 3.3 million interprovincial migrants. Throughout the twentieth century, interprovincial migration increased significantly. In 1971 about 5\% of the total population lived in another province than the province of birth, which was more or less equal to the level of internal migration during the colonial period. However, from the 1970s onwards interprovincial migration increased significantly. In the following decade the number of interprovincial migrants rose to $7.0 \%$, in 1990 it reached $8.2 \%$ and by 2000 it had increased to about $10.1 \%$, indeed roughly double the share of 1930 and 1970.

The - mostly sociological - literature on internal migration in colonial Indonesia points out at least three factors that contributed to interprovincial population movements in Indonesia. Firstly, in the first half of the twentieth century the number of Dutch plantations in the Outer Islands increased strongly. ${ }^{1}$ Since labour was scarce here, planters recruited people from Java. Secondly, in 1905 the Dutch government considered Java to be overpopulated and introduced a program to resettle people from Java to the Outer Islands. Migrant families were given (monetary) migration premiums and could in addition receive a credit, which had to be repaid within a given period of time. Thirdly, the concentration of colonial activity in Java also led to a number of growing urban centres such as present-day Jakarta (which was known as Batavia prior to independence), Surabaya and Semarang (Hugo, 1980, 114). According to Pelzer $(1945,175)$ these cities attracted

\footnotetext{
${ }^{1}$ Due to Java's importance as core region, other parts of the archipelago are usually referred to collectively as the 'Outer Islands'.
} 
people from the crowded interior because of the employment opportunities they offered.

As the figures above pointed out, from the 1970s onwards interprovincial migration in Indonesia remained to be an important phenomenon. The causes for internal migration mentioned in the literature on post-colonial Indonesia are roughly similar to those mentioned in the studies on the Dutch period. The concentration of economic activity on Java and in particular in Jakarta, overall income differentials, and the government policy of transmigration are commonly regarded as the most important explaining factors for interprovincial population movements in Indonesia since independence. Tirtosudarmo (2009), however, speculates that due to substantial reduction in the government capacity to move people under transmigration policy, in recent years migration has become predominantly a function of the labour market economy. The latter is something we will return to in our analysis.

This brief overview of the mostly qualitative literature on internal migration in Indonesia highlights a number of factors that are deemed to be important in determining migration patterns in Indonesia: relative income, migration policy in the shape of transmigration, but also the role of Jakarta as urban primate. In the following section we will not only test the hypotheses whether these factors had indeed a statistical effect, but also determine their relative importance and whether changes over time can be observed.

\section{A gravity model of internal migration in Indonesia, 1930-2000}

Theoretical framework 
In this section we evaluate the factors affecting migration flows between regions by applying a gravity model. The starting point of the gravity model of migration is the assumption that migration is driven by the attractive force between migrant source and destination location and impeded by the costs of moving from one country to another (Ravenstein, 1885, 1889; Zipf, 1946). The hypothesis that people migrate if the expected earnings exceed the costs of the move (using distance as a proxy for the cost of migration) was further developed in the work of Greenwood (1975) and Borjas (1989). The latter proposed a model of immigration, taking into account a set of variables in the host and destination country that can potentially influence the size and composition of the immigrant influx: economic performance; immigration policies, political orientation; and education levels.

Our model is based on the theoretical considerations of Borjas (1989), whose model is built on three basic equations: a wage earning function for the country of origin, one for the country of destination, and a function that takes into account the costs of moving between the two. However, as Karemera et al. (2000) have argued, neither Borjas nor Greenwood provides econometric estimates of the elasticities of migration with regard to the characteristics in their models. Therefore, in this article, we follow the successful approach of Karemera et al. (2000) and Lewer and Van den Berg (2007) in formulating and estimating a gravity model of migration. In doing so we aim to empirically derive migration impact elasticities for the five survey years in our Indonesia dataset. Subsequently, we will compare the impact of the elasticities diachronically, by means of ranking the beta-coefficients derived from the regression analyses for 1930, 1971, 1980, 1990 and 2000. 


\section{The gravity model}

Let us first look at formulation of the basic gravity model, which includes the theoretical assumption mentioned above. The basic assumption of our model is that migration is expected to be positively related to the population in the origin and destination. Ceteris paribus, the more people there are in a source region, the more people are likely to migrate; the larger the population in the destination region, the larger is the labour market for immigrants. In addition, wage differentials between sending and receiving provinces are also likely to influence migration patterns.

Following the neo-classical assumption of the labour market model in which migrants are regarded as rational actors who want to better themselves, differences in wages trigger population movements. At the same time, we assume migration to be negatively related to the distance between sending and receiving region since one is likely to incur higher costs if one needs to travel further. A final factor we control for in our basic model is that people are likely to move to neighbouring provinces - the concept of contiguity. ${ }^{2}$ To control for this phenomenon, we include a contiguity dummy in our model (see also Lewer and Van den Berg, 2007). The foregoing considerations lead to the basic gravity equation

$\ln \left(\mathrm{mig}_{\mathrm{ij}}\right)=\alpha_{0}+\alpha_{1} \ln \left(\mathrm{pop}_{\mathrm{i}}\right)+\alpha_{2} \ln \left(\mathrm{pop}_{\mathrm{j}}\right)+\alpha_{3}$ rely $_{\mathrm{ij}}+\alpha_{4} \ln \left(\mathrm{dist}_{\mathrm{ij}}\right)+\alpha_{5}$ contig $+\mathrm{u}_{\mathrm{ij}}$

where mig $_{\mathrm{ij}}$ represents the migration from source region $\mathrm{i}$ to destination region $\mathrm{j}$, rely $\mathrm{y}_{\mathrm{ij}}$ is the ratio of source region to destination region of log per capita incomes,

\footnotetext{
${ }^{2}$ The effect of the contiguity dummy is not directly captured in the distance variable, since we measure the distance variable as the distance between geographic centres of provinces. Moreover, since some provinces are seperated by sea the distance between these provinces can be large, despite the fact that these provinces share a contiguous border.
} 
dist $_{\mathrm{ij}}$ is the logged distance between source region $\mathrm{i}$ and destination region $\mathrm{j}$, contig is a dummy variable with the value of 1 if provinces have a common boundary and 0 otherwise, and $\mathrm{u}_{\mathrm{ij}}$ is an error term. The expected signs of the coefficients are $\alpha_{1}>0, \alpha_{2}$ $>0, \alpha_{3}<0, \alpha_{4}<0$ and $\alpha_{5}>0$.

The model can be improved by controlling for two other factors: transmigration and urban primacy. We will first deal with the issue of transmigration. The transmigration policy was initiated under Dutch colonial rule during the early twentieth century and taken over by the Indonesian government after independence. Transmigration had three main goals. First of all, the government aimed to use this policy measure to distribute the population more evenly by moving millions of Indonesians from the densely populated islands (Java, Bali, Madura) to the outer, less densely populated islands, indeed to achieve a more balanced demographic development and to alleviate demographic pressure (see Map 1 for an overview of the transmigration provinces). Secondly, it was aimed at the reduction of poverty by providing land and (thus) new opportunities to poor landless settlers.

Finally, the colonial and later national government used this policy measure to exploit more effectively the agricultural potential of the outer islands. To study the effect of transmigration we include a dummy variable

$$
\begin{aligned}
& \ln \left(\operatorname{mig}_{\mathrm{ij}}\right)=\alpha_{0}+\alpha_{1} \ln \left(\text { pop }_{\mathrm{i}}\right)+\alpha_{2} \ln \left(\text { pop }_{\mathrm{j}}\right)+\alpha_{3} \text { rely }_{\mathrm{ij}}+\alpha_{4} \ln \left(\text { dist }_{\mathrm{ij}}\right)+\alpha_{5} \text { contig }+ \\
& \alpha_{6} \text { trans_mig }+\mathrm{u}_{\mathrm{ij}}
\end{aligned}
$$

in which trans_mig is a transmigration dummy, which is 1 for migration from Java to a transmigration region and 0 otherwise. 
The second influence on internal migration in Indonesia we want to control for is urban primacy. A primate city is the major city in a country, which as a result plays a dominant role on different levels. It not only is a city that encapsules a large proportion of the urban population of a country, but is also the political, economical, cultural and transportation center of a nation (Ades and Glaeser, 1995; Henderson, 2000). The general definition is that whenever the ratio of the size of the first to that of the second city exceeds two, the city size is said to be primate (Mutlu, 1989: 611).

Jakarta has clearly been the primate city of Indonesia throughout the twentieth century. At the beginning of the twentyfirst century it was more than twice as populous as the second largest city, Surabaya (in the province of East Java). Jakarta's population in 2005 was 8.8 million which is 3.2 times the population of Surabaya (2.75 million). Moreover, the combined population of Surabaya, Bandung (West Java) and Medan (North Sumatra) in 2005 - the second, third and fourth populous cities in Indonesia respectively - was only 7.1 million: still well below the number of inhabitants of Jakarta (United Nations, World Population Prospects). To study the influence of urban primacy on internal migration patterns in Indonesia we include a dummy variable for Jakarta in the basic gravity model (Equation 1), which suggest the following equation.

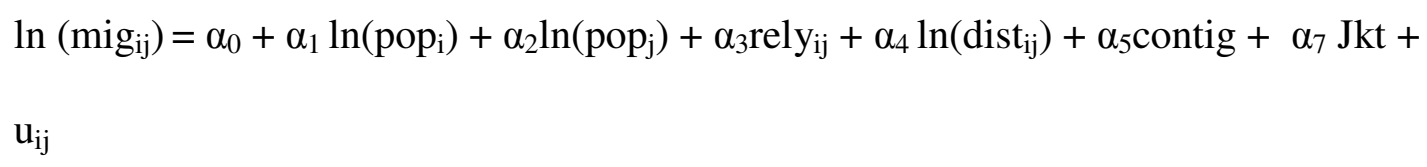

in which Jkt is a dummy which is 1 for migration to Jakarta and 0 otherwise. Clearly, this dummy bears the risk of bringing in the problem of multicollinearity in the 
model, since Jakarta is also the province with relatively high per capita income. Yet, in estimating the model we do not find large changes in the estimated regression coefficients when a predictor variable is added or deleted, and we do not find a high R squared with low values for t-statistics (Alheety and Gore 2009; Bhattacharyya 2009). Neither do the correlation matrices point to this as a problem (see appendix table A2).

The foregoing considerations combined suggests the following augmented gravity equation

$\ln \left(\operatorname{mig}_{\mathrm{ij}}\right)=\alpha_{0}+\alpha_{1} \ln \left(\mathrm{pop}_{\mathrm{i}}\right)+\alpha_{2} \ln \left(\mathrm{pop}_{\mathrm{j}}\right)+\alpha_{3}$ rely $_{\mathrm{ij}}+\alpha_{4} \ln \left(\right.$ dist $\left._{\mathrm{ij}}\right)+\alpha_{5}$ contig + $\alpha_{6}$ trans_mig $+\alpha_{7} \mathrm{Jkt}+\mathrm{u}_{\mathrm{ij}}$

Data

The migration data is based on lifetime migration flows taken from population censuses in 1930, 1971, 1980, 1990 and 2000. In 1930 the Dutch colonial government held a population census in Indonesia, which is considered a wellorganised modern census (Van der Eng 2002: 488). Since Indonesian independence in 1945 population censuses were conducted for the years 1961, 1971, 1980, 1990 and 2000. Yet, unfortunately, the 1961 census does not contain information on migration flows.

The available data provides matrices consisting of 650 migration flows between the provinces of Indonesia for the respective benchmark years. For the years 1930 and 2000 we had to make some adaptations, because in these survey years Indonesia's provincial division differed from the intermediate ones. Currently, 
Indonesia consists of 33 provinces, seven of which have been created since 2000 . In 1930 the colonial government had divided the Netherlands-Indies in 36

administrative regions. For consistency we consolidated these 36 administrative regions and 33 provinces in 2000 and into 26 provinces, which were in place between 1971 and 2000 (see Map 1).

The distance variable in our analysis was calculated between the geographic centres (or centroids) of the provinces using ArcGis software. Since 1970, data on regional Gross Domestic Product (GDP) per capita has been published by the Indonesian Central Bureau of Statistics (BPS) in their annual statistical yearbooks. For 1930 we had to rely on provincial wage data taken from Dros (1992).

\section{Results}

Table 1 provides the regression results for the 4 models in the 5 benchmark years. All estimated variables have the expected sign and almost all are statistically significant at the $1 \%$ level. In all cases the simple gravity model (Equation 1) already explains at least $57.2 \%$ of the observed variation in the depended variable interprovincial migration, which increases when the dummy variables for transmigration (Equation 2) and urban primacy are estimated (Equation 3). In all instances the highest (adjusted) R square is reached in the most elaborate model (Equation 4) with a minimum of 0.60 in 1971 and a maximum of 0.69 in 1990.

A number of interesting results emerge from the regression analysis, from which we want to point out three main issues. Firstly, our analysis demonstrates that the transmigration dummy is not only insignificant for 1930, 1971 and 1980, the coefficients are also very small during these years. This confirms more qualitative 
studies evaluating transmigration until the 1980s (Van der Wijst, 1985; World Bank, 1988). For 1990 and 2000, however, transmigration has a statistically significant effect on migration patterns. This can be attributed to renewed focus on transmigration since the 1980s. Substantial loans by the World Bank and the Asian Development Bank, combined with bilateral financial assistance made it possible to expand the transmigration programme. As a consequence in the period 1980-1990 ten times more people were resettled than in the decades since the beginning of statesponsored transmigration (Adhiati and Bobsien, 2001). Resettlement figures remained high in the first half of the 1990s, but the programme collapsed as a result of the Asian Crisis. Nevertheless, the ranking of the beta-coefficients in Table 2 reveals that the effect of the transmigration policy - mainly due to massive financial input - became statistically significant from the 1990s onwards and also showed that its effect was higher in magnitude compared to other years. Still, its impact remained relatively limited compared to other factors: table 2 shows that the beta rank of the transmigration dummy was seventh for the years 1930, 1971 and 1980, only fifth for 1990 and 2000.

Secondly, a strikingly important determinant of migration patterns in Indonesia is the role of urban primacy, as proxied by our Jakarta dummy. Since Indonesia's independence in the 1940s this variable has become the dominant factor in explaining internal migration patterns. Clearly, the island of Java isIndonesia's economic core region, and Jakarta is the centre of this core. This explains its attractiveness for migrants through three channels. First of all, as Krugman and Livas (1992) have demonstrated in their study on Mexico City, net transport costs are lower for domestic goods in the central city because firms are located in that city. As a result workers come to the city attracted by the relatively lower prices for domestic 
goods. Another factor that explains the significant effect of the Jakarta dummy is Indonesia's trade and price intervention. In general, the Indonesian government adopts a policy of protecting manufacturing activities and taxes primary sector based activities. This has led to protection of the urban sector of Java, and Jakarta in particular (Garcia-Garcia, 2000). Finally, since its independence Jakarta has also been Indonesia's political core. As suggested by Ades and Glaeser (1995), urban giant leaders often extract wealth out of the hinterlands and distribute in the capital. This pulls migrants to the city because of the demand created by the concentration of wealth. Our analysis indicates that this theory can also be applied to Indonesia.

Finally, the theory that underpins the basic gravity model predicts that wage differentials between sending and receiving regions are likely to be an important determinant in a well functioning, open economy and corresponding labour market. Interestingly, the results of our estimation show that this variable was not an important determinant of interprovincial migration in Indonesia. The most likely explanation for this is the fact that Indonesia is characterized by a dual labour market, with a rigid formal market and a widespread informal sector. In 2010 no less than 68.6 per cent of the labour force was employed in the informal sector (OECD 2010). In additions, our relative wage variable measures provincial per capital GDP rather than actual income in the informal sector. As Harris and Todaro (1970) have argued, an important determinant for migration is expected rather than actual income differentials. Most likely we are unable to capture the (expected) income dynamics in the informal sector, where indeed most of the migrants end up.

\section{Concluding remarks}


This study applied a gravity model of model of migration on interprovincial migration in Indonesia between 1930 and 2000. The theoretical framework of our study was Borjas' (1989) model of migration, while the application of the traditional gravity model on migration flows was based on the work of Lewer and Van den Berg (2007) and Karemera et al. (2000). In order to capture the potential determinants of internal migration flows we augmented the traditional gravity model by including variables dealing with contiguity, migration policy and urban primacy.

This article demonstrated that the gravity model is very suitable for an analysis of internal migration flows in a large developing country such as Indonesia, not only for relatively recent migration flows, but also for more historical migration movements. Our analysis showed that all in all five survey years, from 1930 up until 2000, the signs of the coefficients was as expected, and the augmented gravity model explained a very large portion of the variation of the dependent variable, internal migration. Given that the number of empirical studies that apply gravity models on migration is still relatively limited, and the fact the application of the gravity model on Indonesian migration flows for over a period of 70 years - covering different political and economic settings - was successful, our study should thus be regarded as a next step in the testing of the robustness and overall validity of the model.

Our analysis showed that in Indonesia between 1930 and 2000 wage differentials between sending and receiving provinces where relatively unimportant, while the presence of an urban primate in the shape of Jakarta was the most important determinant of migration. Nevertheless, the fact that other factors seemed to have had less influence is perhaps equally interesting. One of the main conclusions of this study is that a policy of supported migration (transmigration in the Indonesian case) is not only costly, but also of relatively limited effect. Our 
regression analysis showed that migrants have a tendency to base their decision on the more tangible prospect of economic betterment, either in the shape of improvements of one's (expected) income or the attractiveness of moving to a primate city, than on the less concrete prospect of moving to a region that lacks these features - even if this move is supported financially by the government. This in turn suggests that in order to influence migration patterns, for instance as a means of alleviating demographic pressure or to even out the negative effects of lopsided regional economic growth, it seems more effective to focus on the development of less developed regions directly than simply to promote migration to them and thus create economic development in an in-direct way. Indonesia is in this respect an interesting case since it already has adopted decentralization measures since the beginning of the twenty-first century, and as such has begun to redistribute power and wealth; as a result in recent years Jakarta has already lost importance as economic and political core. Whether this will in fact result in different interprovincial migration patterns, i.e. a less central role for Jakarta, and thus a more evenly distributed population, as indeed our analysis suggests, is yet too early to tell and is therefore a topic for future research. 


\section{References}

Alheety, M. I.; Gore, S. D. (2009), 'Two Strategies for Removing Multicollinearity', Bulletin of Statistics and Economics, 3, pp. 62-79.

Ades, A. F. And E. L. Glaeser (1995) Trade and Circuses: Explaining Urban Giants, The Quarterly Journal of Economics, 110, pp. 195-227.

Adhiati, M. A. S.. and Bobsien, A. (2001) Indonesia's Transmigration Programme: an Update, Report for Down to Earth, International Campaign for Ecological Justice in Indonesia. Available at http://dte.gn.apc.org/ctrans.htm (accessed 15 February 2010).

Bhattacharyya, S. (2009), 'Unbundled Institutions, Human Capital and Growth', Journal of Comparative Economics, 37, pp. 106-120.

Borjas, J.G. (1989) Economic Theory and International Migration, International Migration Review, 23, pp. 457-485.

Dros, N. (1992), Changing Economy in Indonesia: a Selection of Statistical Source Material from the Early 19th Century up to 1940, Volume 13: Wages 1820-1940, Amsterdam

Garcia-Garcia, J. (2000) Indonesia's Trade and Price Interventions: Pro-Java and Pro-Urban, Bulletin of Indonesian Economic Studies, 36, pp. 93-112. 
Greenwood, M. (1975) Research on Internal Migration in the United States: a Survey, Journal of Economic Literature, 13, pp. 397-433.

Harris, J.R. and Todaro, N.O., 'Migration, unemployment and development: a two sector analysis', The American Economic Review, 60 (1970), pp. 126-142.

Henderson, V. (2000) How Urban Concentration Affects Economic Growth, World Bank Policy Research Working Paper No. 2326, World Bank.

Karemera, D, Iwuagwu Oguledo, V., and Davis, B. (2000) A Gravity Model Analysis of International Migration to North America, Applied Economics, 32, pp. $1745-1755$.

Krugman, P. and Livas, R. (1992) Trade Policy and Third World Metropolis, NBER Working Paper No. 4238, NBER, Cambridge, Mass.

Lewer, J. J. and Van den Berg, H. (2008) A Gravity Model of Immigration, Economics Letters, 99, pp. 164-167.

Mutlu, S. (1989) Urban Concentration and Primacy Revisited: An Analysis and Some Policy Conclusions, Economic Development and Cultural Change, 37, pp. 611-639.

OECD (2010), OECD Economic Surveys Indonesia, OECD, Paris. 
Pelzer, K. J. (1945), Pioneer Settlement in the Asiatic Tropics, New Haven: Yale University Press.

Ravenstein, E. (1885) The Laws of Migration, Journal of the royal Statistical Society, 48, pp. 167-235.

Ravenstein, E. (1889) The Laws of Migration: Second Paper, Journal of the Royal Statistical Society, 52, pp. 241-305.

Tirtosudarmo, R. (2009), Mobility and Human Development in Indonesia, UNDP Human Development Research Paper 2009/19, United Nations, New York.

Eng, Pierre van der (2002), Bridging a Gap: Reconstruction of Population Patterns in Indonesia, 1930-61, Asian Studies Review, 26, pp. 487 - 509.

Van der Wijst, T. (1985), Transmigration in Indonesia: An Evaluation of a Population Redistribution Policy, Population Research and Policy Review, 4, pp. 130.

World Bank (1988) Indonesia: The Transmigration Program in Perspective, Washington DC.

Zipf, G. (1946) The $\mathrm{P}_{1} \mathrm{P}_{2} / \mathrm{D}$ hypothesis: on the Intercity Movement of Persons, American Sociological Review, 11, pp. 677-686. 
Volkstelling 1930, Landsdrukkerij, Batavia. 
Table 1. Regression results

\begin{tabular}{|c|c|c|c|c|}
\hline & $\begin{array}{l}\text { Gravity model } \\
\text { of migration }\end{array}$ & $\begin{array}{l}\text { Testing for } \\
\text { urban primacy } \\
\text { effect }\end{array}$ & $\begin{array}{l}\text { Testing for } \\
\text { transmigration } \\
\text { effect }\end{array}$ & $\begin{array}{l}\text { Extended gravity } \\
\text { model }\end{array}$ \\
\hline & (1) & (2) & (3) & (4) \\
\hline \multicolumn{5}{|l|}{1930} \\
\hline $\mathrm{Pop}_{\mathrm{i}}$ & $0.608(16.2)^{* *}$ & $0.608(16.3)^{* *}$ & $0.621(15.4)^{* *}$ & $0.623(15.4)^{* *}$ \\
\hline $\mathrm{Pop}_{\mathrm{j}}$ & $0.236(6.24)^{* *}$ & $0.230(6.09)^{* *}$ & $0.233(6.17)^{* *}$ & $0.227(6.00)^{* *}$ \\
\hline Rely $_{\mathrm{ij}}$ & $-0.126(-3.06)^{* *}$ & $-0.126(-3.07)^{* *}$ & $-0.137(-3.18)^{* *}$ & $-0.139(-3.21)^{* *}$ \\
\hline $\mathrm{D}_{\mathrm{ij}}$ & $-0.619(-5.26)^{* *}$ & $-0.223(-5.10)^{* *}$ & $-0.222(-5.01)^{* *}$ & $-0.215(-4.83)^{* *}$ \\
\hline $\begin{array}{l}\text { Contiguity } \\
\text { dummy }\end{array}$ & $0.611(4.57)^{* *}$ & $0.617(4.62)^{* *}$ & $0.628(4.64)^{* *}$ & $0.635(4.71)^{* *}$ \\
\hline Jkt dummy & & $0.255(1.72)$ & & $0.261(1.77)$ \\
\hline $\begin{array}{l}\text { Transmigration } \\
\text { dummy }\end{array}$ & & & $-0.077(-0.87)$ & $-0.085(-0.06)$ \\
\hline $\mathrm{N}$ & 340 & 340 & 340 & 340 \\
\hline $\mathrm{R}^{2}$ & 0.617 & 0.620 & 0.617 & 0.621 \\
\hline Adj. $R^{2}$ & 0.612 & 0.614 & 0.612 & 0.614 \\
\hline \multicolumn{5}{|l|}{1971} \\
\hline $\mathrm{Pop}_{i}$ & $0.630(16.8)^{* *}$ & $0.602(16.6)^{* *}$ & $0.640(16.0)^{* *}$ & $0.615(15.9)^{* *}$ \\
\hline Pop $_{1}$ & $0.192(5.38)^{* *}$ & $0.199(5.80)^{* *}$ & $0.189(5.27)^{* *}$ & $0.195(5.66)^{* *}$ \\
\hline Rely $_{\mathrm{ij}}$ & $-0.273(-6.14)^{* *}$ & $-0.220(-5.07)^{* *}$ & $-0.273(-6.14)^{* *}$ & $-0.220(-5.08)^{* *}$ \\
\hline $\mathrm{D}_{\mathrm{ij}}$ & $-0.287(-8.24)^{* *}$ & $-0.278(-8.30)^{* *}$ & $-0.283(-8.02)^{* *}$ & $-0.272(-8.03)^{* *}$ \\
\hline $\begin{array}{l}\text { Contiguity } \\
\text { dummy }\end{array}$ & $0.421(3.79)^{* *}$ & $0.427(3.99)^{* *}$ & $0.431(3.84)^{* *}$ & $0.439(4.08)^{* *}$ \\
\hline Jkt dummy & & $0.929(7.18)^{* *}$ & & $0.933(7.20)^{* *}$ \\
\hline $\begin{array}{l}\text { Transmigration } \\
\text { dummy }\end{array}$ & & & $-0.046(-0.71)$ & $-0.060(-0.96)$ \\
\hline $\mathrm{N}$ & 623 & 623 & 623 & 623 \\
\hline $\mathrm{R}^{2}$ & 0.570 & 0.603 & 0.571 & 0.604 \\
\hline Adj. $R^{2}$ & 0.567 & 0.600 & 0.567 & 0.600 \\
\hline \multicolumn{5}{|l|}{1980} \\
\hline $\mathrm{Pop}_{\mathrm{i}}$ & $0.637(22.3)^{* *}$ & $0.617(22.5)^{* *}$ & $0.634(20.0)^{* *}$ & $0.615(20.3)^{* *}$ \\
\hline Pop $_{i}$ & $0.196(6.94)^{* *}$ & $0.205(7.62)^{* *}$ & $0.197(6.88)^{* *}$ & $0.206(7.54)^{* *}$ \\
\hline Rely $_{\mathrm{ij}}$ & $-0.164(-5.05)^{* *}$ & $-0.117(-3.71)^{* *}$ & $-0.163(-5.01)^{* *}$ & $-0.116(-3.69)^{* *}$ \\
\hline $\mathrm{D}_{\mathrm{ij}}$ & $-0.370(-12.2)^{* *}$ & $-0.357(-12.3)^{* *}$ & $-0.371(-12.1)^{* *}$ & $-0.358(-12.2)^{* *}$ \\
\hline $\begin{array}{l}\text { Contiguity } \\
\text { dummy }\end{array}$ & $0.284(2.85)^{* *}$ & $0.295(3.12)^{* * *}$ & $0.281(2.81)^{* *}$ & $0.294(3.08)^{* *}$ \\
\hline Jkt dummy & & $0.938(8.06)^{* *}$ & & $0.938(8.05)^{* *}$ \\
\hline $\begin{array}{l}\text { Transmigration } \\
\text { dummy }\end{array}$ & & & $0.013(0.22)$ & $0.009(0.16)$ \\
\hline $\mathrm{N}$ & 641 & 641 & 641 & 641 \\
\hline $\mathrm{R}^{2}$ & 0.645 & 0.678 & 0.645 & 0.678 \\
\hline Adj. $R^{2}$ & 0.643 & 0.675 & 0.642 & 0.675 \\
\hline
\end{tabular}




\begin{tabular}{|c|c|c|c|c|}
\hline & $\begin{array}{l}\text { Gravity model } \\
\text { of migration }\end{array}$ & $\begin{array}{l}\text { Testing for } \\
\text { urban primacy } \\
\text { effect }\end{array}$ & $\begin{array}{l}\text { Testing for } \\
\text { transmigration } \\
\text { effect }\end{array}$ & $\begin{array}{l}\text { Extended gravity } \\
\text { model }\end{array}$ \\
\hline & $(1)$ & $(2)$ & (3) & (4) \\
\hline \multicolumn{5}{|l|}{1990} \\
\hline $\mathrm{Pop}_{\mathrm{i}}$ & $0.549(23.8)^{* *}$ & $0.550(24.5)^{* *}$ & $0.502(19.7)^{* *}$ & $0.504(20.3)^{* *}$ \\
\hline Pop $_{j}$ & $0.274(11.9)^{* *}$ & $0.255(11.2)^{* *}$ & $0.287(12.5)^{* *}$ & $0.268(11.8)^{* *}$ \\
\hline Rely $_{\mathrm{ij}}$ & $-0.120(-5.30)^{* *}$ & $-0.090(-3.95)^{* *}$ & $-0.116(-5.18)^{* *}$ & $-0.086(-3.84)^{* *}$ \\
\hline $\mathrm{D}_{\mathrm{ij}}$ & $-0.407(-13.9)^{* * *}$ & $-0.400(-14.0)^{* *}$ & $-0.423(-14.5)^{* *}$ & $-0.415(-14.6)^{* *}$ \\
\hline $\begin{array}{l}\text { Contiguity } \\
\text { dummy }\end{array}$ & $0.165(1.71)$ & $0.171(1.82)$ & $0.126(1.32)$ & $0.133(1.43)$ \\
\hline Jkt dummy & & $1.601(6.26)^{* *}$ & & $0.683(7.08)^{* *}$ \\
\hline $\begin{array}{l}\text { Transmigration } \\
\text { dummy }\end{array}$ & & & $0.232(4.14)^{* *}$ & $0.225(4.11)^{* *}$ \\
\hline $\mathrm{N}$ & 650 & 650 & 650 & 650 \\
\hline $\mathrm{R}^{2}$ & 0.668 & 0.685 & 0.677 & 0.693 \\
\hline Adj. $R^{2}$ & 0.666 & 0.683 & 0.674 & 0.690 \\
\hline \multicolumn{5}{|l|}{2000} \\
\hline $\mathrm{Pop}_{\mathrm{i}}$ & $0.509(21.8)^{* *}$ & $0.515(22.5)^{* *}$ & $0.469(18.1)^{* *}$ & $0.477(18.7)^{* *}$ \\
\hline Pop $_{j}$ & $0.277(11.9)^{* *}$ & $0.263(11.5)^{* *}$ & $0.288(12.4)^{* *}$ & $0.274(11.9)^{* *}$ \\
\hline Rely $_{\mathrm{ij}}$ & $-0.143(-6.23)^{* *}$ & $-0.109(-4.60)^{* *}$ & $-0.147(-6.43)^{* *}$ & $-0.113(-4.81)^{* *}$ \\
\hline $\mathrm{D}_{\mathrm{ij}}$ & $-0.419(-14.42)^{* *}$ & $-0.411(-14.2)^{* *}$ & $-0.432(-14.6)^{* *}$ & $-0.424(-14.6)^{* *}$ \\
\hline $\begin{array}{l}\text { Contiguity } \\
\text { dummy }\end{array}$ & $0.182(1.89)^{*}$ & $0.189(2.01)^{*}$ & $0.149(1.55)$ & $0.158(1.68)$ \\
\hline Jkt dummy & & $0.590(4.94)^{* *}$ & & $0.575(4.84)^{* *}$ \\
\hline $\begin{array}{l}\text { Transmigration } \\
\text { dummy }\end{array}$ & & & $0.192(3.40)^{* *}$ & $0.181(3.27)^{* *}$ \\
\hline $\mathrm{N}$ & 650 & 650 & 650 & 650 \\
\hline $\mathrm{R}^{2}$ & 0.669 & 0.681 & 0.675 & 0.686 \\
\hline Adj. $R^{2}$ & 0.667 & 0.678 & 0.672 & 0.683 \\
\hline
\end{tabular}

Note: **: denotes test statistics significance at the $1 \%$ level; *: significant at the $5 \%$ level. 
Table 2. Estimated beta coefficients

\begin{tabular}{cccccccccccc}
\hline & \multicolumn{2}{c}{ 1930 } & \multicolumn{2}{c}{1971} & \multicolumn{2}{c}{$\mathbf{1 9 8 0}$} & \multicolumn{2}{c}{$\mathbf{1 9 9 0}$} & \multicolumn{2}{c}{$\mathbf{2 0 0 0}$} \\
& Beta & Rank & Beta & Rank & Beta & Rank & Beta & Rank & Beta & Rank \\
\hline Popi & 0.623 & 2 & 0.615 & 2 & 0.615 & 2 & 0.504 & 2 & 0.477 & 2 \\
Popj & 0.227 & 4 & 0.195 & 6 & 0.206 & 5 & 0.268 & 4 & 0.274 & 4 \\
Relw & -0.139 & 6 & -0.220 & 5 & -0.116 & 6 & -0.086 & 7 & -0.113 & 7 \\
D & -0.215 & 5 & -0.272 & 4 & -0.358 & 3 & -0.415 & 3 & -0.424 & 3 \\
Contiguity & 0.635 & 1 & 0.439 & 3 & 0.294 & 4 & 0.133 & 6 & 0.158 & 6 \\
Jkt dummy & 0.261 & 3 & 0.933 & 1 & 0.938 & 1 & 0.683 & 1 & 0.575 & 1 \\
$\begin{array}{c}\text { Transmigration } \\
\text { dummy }\end{array}$ & -0.085 & 7 & -0.060 & 7 & 0.009 & 7 & 0.225 & 5 & 0.181 & 5 \\
\hline
\end{tabular}




\section{Appendix}

Table A1: summary statistics

\begin{tabular}{|c|c|c|c|c|c|c|c|c|}
\hline & $\begin{array}{l}\text { Transmigrat } \\
\text { ion dummy }\end{array}$ & Lmigij & LPopi & LPopj & LDij & Relyij & Jkt_dummy & Cont \\
\hline \multicolumn{9}{|c|}{1930} \\
\hline Mean & 0,23 & 6,22 & 14,19 & 14,18 & 6,91 & 1,01 & 0,05 & 0,11 \\
\hline Median & 0,00 & 6,20 & 14,10 & 14,10 & 6,95 & 1,00 & 0,00 & 0,00 \\
\hline Standard Deviation & 0,42 & 2,21 & 1,17 & 1,18 & 0,72 & 0,11 & 0,22 & 0,31 \\
\hline Sample Variance & 0,18 & 4,89 & 1,37 & 1,38 & 0,52 & 0,01 & 0,05 & 0,09 \\
\hline Kurtosis & $-0,33$ & $-0,40$ & $-0,45$ & $-0,47$ & 0,64 & $-0,07$ & 14,17 & 4,65 \\
\hline Skewness & 1,29 & 0,24 & 0,36 & 0,36 & $-0,77$ & 0,29 & 4,01 & 2,57 \\
\hline Range & 1,00 & 10,64 & 4,09 & 4,09 & 3,89 & 0,55 & 1,00 & 1,00 \\
\hline Minimum & 0,00 & 1,61 & 12,37 & 12,37 & 4,30 & 0,76 & 0,00 & 0,00 \\
\hline Maximum & 1,00 & 12,24 & 16,45 & 16,45 & 8,20 & 1,31 & 1,00 & 1,00 \\
\hline Count & 340 & 340 & 340 & 340 & 340 & 340 & 340 & 340 \\
\hline \multicolumn{9}{|c|}{1971} \\
\hline Mean & 0,21 & 6,46 & 14,65 & 14,63 & 7,04 & 1,07 & 0,04 & 0,09 \\
\hline Median & 0,00 & 6,39 & 14,57 & 14,57 & 7,12 & 1,00 & 0,00 & 0,00 \\
\hline Standard Deviation & 0,41 & 2,38 & 1,14 & 1,16 & 0,69 & 0,39 & 0,20 & 0,29 \\
\hline Sample Variance & 0,17 & 5,69 & 1,30 & 1,36 & 0,48 & 0,15 & 0,04 & 0,08 \\
\hline Kurtosis & 0,00 & $-0,26$ & 0,42 & 0,37 & 0,71 & 0,42 & 20,13 & 6,09 \\
\hline Skewness & 1,41 & 0,06 & 0,36 & 0,29 & $-0,71$ & 0,81 & 4,70 & 2,84 \\
\hline Range & 1,00 & 13,55 & 5,13 & 5,13 & 4,13 & 2,07 & 1,00 & 1,00 \\
\hline Minimum & 0,00 & 0,00 & 11,92 & 11,92 & 4,30 & 0,40 & 0,00 & 0,00 \\
\hline Maximum & 1,00 & 13,55 & 17,05 & 17,05 & 8,43 & 2,48 & 1,00 & 1,00 \\
\hline Count & 623 & 623 & 623 & 623 & 623 & 623 & 623 & 623 \\
\hline \multicolumn{9}{|c|}{1980} \\
\hline Mean & 0,21 & 7,32 & 14,88 & 14,87 & 7,05 & 1,03 & 0,04 & 0,09 \\
\hline Median & 0,00 & 7,25 & 14,76 & 14,76 & 7,13 & 1,00 & 0,00 & 0,00 \\
\hline Standard Deviation & 0,41 & 2,14 & 1,04 & 1,04 & 0,69 & 0,25 & 0,19 & 0,29 \\
\hline Sample Variance & 0,16 & 4,57 & 1,07 & 1,07 & 0,48 & 0,06 & 0,04 & 0,08 \\
\hline Kurtosis & 0,09 & $-0,34$ & 0,33 & 0,33 & 0,73 & $-0,30$ & 20,85 & 6,21 \\
\hline Skewness & 1,45 & 0,27 & 0,98 & 0,99 & $-0,72$ & 0,49 & 4,77 & 2,86 \\
\hline Range & 1,00 & 10,81 & 3,79 & 3,79 & 4,13 & 1,23 & 1,00 & 1,00 \\
\hline Minimum & 0,00 & 2,83 & 13,44 & 13,44 & 4,30 & 0,56 & 0,00 & 0,00 \\
\hline Maximum & 1,00 & 13,65 & 17,23 & 17,23 & 8,43 & 1,79 & 1,00 & 1,00 \\
\hline Count & 641 & 641 & 641 & 641 & 641 & 641 & 641 & 641 \\
\hline
\end{tabular}

Editorial Office, Dept of Economics, Warwick University, Coventry CV4 7AL, UK 


\begin{tabular}{|c|c|c|c|c|c|c|c|c|}
\hline & $\begin{array}{l}\text { Transmigrat } \\
\text { ion dummy }\end{array}$ & Lmigij & LPopi & LPopj & LDij & Relyij & Jkt_dummy & Cont \\
\hline \multicolumn{9}{|c|}{1990} \\
\hline Mean & 0,20 & 7,82 & 15,18 & 15,18 & 7,06 & 1,01 & 0,04 & 0,09 \\
\hline Median & 0,00 & 7,67 & 14,99 & 14,99 & 7,13 & 1,00 & 0,00 & 0,00 \\
\hline Standard Deviation & 0,40 & 2,13 & 0,94 & 0,94 & 0,69 & 0,13 & 0,19 & 0,29 \\
\hline Sample Variance & 0,16 & 4,55 & 0,88 & 0,88 & 0,47 & 0,02 & 0,04 & 0,08 \\
\hline Kurtosis & 0,15 & $-0,40$ & 0,34 & 0,34 & 0,74 & 0,50 & 21,21 & 6,36 \\
\hline Skewness & 1,47 & 0,20 & 1,07 & 1,07 & $-0,74$ & 0,43 & 4,81 & 2,89 \\
\hline Range & 1,00 & 11,46 & 3,40 & 3,40 & 4,13 & 0,78 & 1,00 & 1,00 \\
\hline Minimum & 0,00 & 2,48 & 13,98 & 13,98 & 4,30 & 0,68 & 0,00 & 0,00 \\
\hline Maximum & 1,00 & 13,95 & 17,38 & 17,38 & 8,43 & 1,46 & 1,00 & 1,00 \\
\hline Count & 650 & 650 & 650 & 650 & 650 & 650 & 650 & 650 \\
\hline \multicolumn{9}{|c|}{2000} \\
\hline Mean & 0,20 & 8,20 & 15,23 & 15,23 & 7,06 & 1,01 & 0,04 & 0,09 \\
\hline Median & 0,00 & 8,20 & 15,05 & 15,05 & 7,13 & 1,00 & 0,00 & 0,00 \\
\hline Standard Deviation & 0,40 & 2,09 & 0,99 & 0,99 & 0,69 & 0,12 & 0,19 & 0,29 \\
\hline Sample Variance & 0,16 & 4,37 & 0,99 & 0,99 & 0,47 & 0,01 & 0,04 & 0,08 \\
\hline Kurtosis & 0,15 & $-0,37$ & 0,30 & 0,30 & 0,74 & 0,42 & 21,21 & 6,36 \\
\hline Skewness & 1,47 & 0,15 & 1,06 & 1,06 & $-0,74$ & 0,39 & 4,81 & 2,89 \\
\hline Range & 1,00 & 11,29 & 3,47 & 3,47 & 4,13 & 0,75 & 1,00 & 1,00 \\
\hline Minimum & 0,00 & 2,94 & 14,06 & 14,06 & 4,30 & 0,69 & 0,00 & 0,00 \\
\hline Maximum & 1,00 & 14,23 & 17,54 & 17,54 & 8,43 & 1,45 & 1,00 & 1,00 \\
\hline Count & 650 & 650 & 650 & 650 & 650 & 650 & 650 & 650 \\
\hline
\end{tabular}




\section{Table A2: Correlation matrix}

\begin{tabular}{|c|c|c|c|c|c|c|c|c|}
\hline & $\begin{array}{c}\text { Transmigration } \\
\text { dummy }\end{array}$ & Lmigij & LPopi & LPopj & LDij & Relyij & Jkt_dummy & Cont \\
\hline \multicolumn{9}{|l|}{1930} \\
\hline Transmigration dummy & 1 & & & & & & & \\
\hline Lmigij & 0,295 & 1 & & & & & & \\
\hline LPopi & 0,546 & 0,646 & 1 & & & & & \\
\hline LPopj & $-0,252$ & 0,159 & $-0,054$ & 1 & & & & \\
\hline LDij & 0,105 & $-0,382$ & $-0,031$ & $-0,037$ & 1 & & & \\
\hline RelLWcoolieij & $-0,556$ & $-0,272$ & $-0,401$ & 0,423 & $-0,002$ & 1 & & \\
\hline Jkt_dummy & $-0,129$ & 0,104 & $-0,008$ & 0,106 & $-0,100$ & 0,051 & 1 & \\
\hline Cont & $-0,165$ & 0,344 & $-0,035$ & 0,004 & $-0,663$ & $-0,014$ & $-0,039$ & 1 \\
\hline \multicolumn{9}{|l|}{1971} \\
\hline Transmigration dummy & 1 & & & & & & & \\
\hline Lmigij & 0,137 & 1 & & & & & & \\
\hline LPopi & 0,494 & 0,501 & 1 & & & & & \\
\hline LPopj & $-0,198$ & 0,360 & $-0,063$ & 1 & & & & \\
\hline LDij & 0,056 & $-0,507$ & $-0,169$ & $-0,180$ & 1 & & & \\
\hline relyij & 0,384 & 0,003 & 0,614 & $-0,558$ & 0,006 & 1 & & \\
\hline Jkt_dummy & $-0,106$ & 0,266 & $-0,014$ & 0,122 & $-0,065$ & $-0,174$ & 1 & \\
\hline Cont & $-0,137$ & 0,339 & 0,017 & 0,033 & $-0,639$ & $-0,016$ & $-0,037$ & 1 \\
\hline \multicolumn{9}{|c|}{1980} \\
\hline Transmigration dummy & 1 & & & & & & & \\
\hline Lmigij & 0,225 & 1 & & & & & & \\
\hline LPopi & 0,499 & 0,591 & 1 & & & & & \\
\hline LPopj & $-0,191$ & 0,294 & $-0,047$ & 1 & & & & \\
\hline LDij & 0,048 & $-0,524$ & $-0,122$ & $-0,126$ & 1 & & & \\
\hline relyij & 0,275 & 0,064 & 0,506 & $-0,484$ & $-0,002$ & 1 & & \\
\hline Jkt_dummy & $-0,103$ & 0,248 & $-0,006$ & 0,077 & $-0,067$ & $-0,175$ & 1 & \\
\hline Cont & $-0,135$ & 0,335 & 0,005 & 0,0243 & $-0,636$ & $-0,012$ & $-0,035$ & 1 \\
\hline
\end{tabular}

Editorial Office, Dept of Economics, Warwick University, Coventry CV4 7AL, UK 


\begin{tabular}{|c|c|c|c|c|c|c|c|c|}
\hline \multicolumn{9}{|l|}{1990} \\
\hline Transmigration dummy & 1 & & & & & & & \\
\hline Lmigij & 0,297 & 1 & & & & & & \\
\hline LPopi & 0,483 & 0,595 & 1 & & & & & \\
\hline LPopj & $-0,178$ & 0,313 & $-0,04$ & 1 & & & & \\
\hline LDij & 0,042 & $-0,553$ & $-0,140$ & $-0,140$ & 1 & & & \\
\hline relyij & $-0,039$ & $-0,126$ & 0,004 & $-0,021$ & 0,005 & 1 & & \\
\hline Jkt_dummy & $-0,101$ & 0,225 & $-0,006$ & 0,158 & $-0,069$ & $-0,232$ & 1 & \\
\hline Cont & $-0,132$ & 0,329 & 0,016 & 0,034 & $-0,635$ & $-0,006$ & $-0,035$ & 1 \\
\hline \multicolumn{9}{|l|}{2000} \\
\hline \multicolumn{9}{|l|}{ Transmigration dummy } \\
\hline Lmigij & 0,262 & 1 & & & & & & \\
\hline LPopi & 0,485 & 0,585 & 1 & & & & & \\
\hline LPopj & $-0,1788$ & 0,308 & $-0,04$ & 1 & & & & \\
\hline LDij & 0,042 & $-0,577$ & $-0,158$ & $-0,158$ & 1 & & & \\
\hline relyij & $-0,038$ & $-0,184$ & $-0,136$ & 0,116 & 0,009 & 1 & & \\
\hline Jkt_dummy & $-0,101$ & 0,202 & $-0,004$ & 0,096 & $-0,069$ & $-0,284$ & 1 & \\
\hline Cont & $-0,132$ & 0,347 & 0,023 & 0,040 & $-0,635$ & $-0,007$ & $-0,035$ & 1 \\
\hline \multicolumn{9}{|l|}{ Total sample, 1930-2000 } \\
\hline Transmigration dummy & 1 & & & & & & & \\
\hline Lmigij & 0,219 & 1 & & & & & & \\
\hline LPopi & 0,467 & 0,611 & 1 & & & & & \\
\hline LPopj & $-0,191$ & 0,364 & 0,052 & 1 & & & & \\
\hline LDij & 0,053 & $-0,478$ & $-0,108$ & $-0,112$ & 1 & & & \\
\hline relyij & 0,163 & $-0,051$ & 0,292 & $-0,296$ & 0,004 & 1 & & \\
\hline Jkt_dummy & $-0,106$ & 0,202 & $-0,013$ & 0,100 & $-0,073$ & $-0,158$ & 1 & \\
\hline Cont & $-0,138$ & 0,317 & 0,003 & 0,023 & $-0,640$ & $-0,011$ & $-0,035$ & 1 \\
\hline
\end{tabular}


